\title{
Stem and Root Resistance to Tobacco Black Shank
}

\author{
A. S. Csinos, Professor, Department of Plant Pathology, University of Georgia Coastal Plain Experiment Station, \\ Tifton 31793-0748
}

\author{
ABSTRACT \\ Csinos, A. S. 1999. Stem and root resistance to tobacco black shank. Plant Dis. 83:777-780.
}

Stem lesion development in the absence of root decay in tobacco black shank caused by Phytophthora parasitica var. nicotianae has become common in the Coastal Plain tobacco growing area in Georgia. All aboveground symptoms of wilting, blackening of lower stem, and destruction of the pith can occur on tobacco without or with minor root decay. This type of black shank disease development occurred in 14 of 15 locations evaluated and accounted for about $30 \%$ of diseased plants. Cultivars with Florida 301-derived resistance had very low stem resistance to race 0 of the pathogen. However, root inoculations of these cultivars resulted in disease reactions typical of those expected in vivo in Georgia. Cultivars Coker 371-Gold and NC 71 and the breeding line 1071 demonstrated high resistance to inoculation with race 0 of $P$. parasitica var. nicotianae in both the stem and the roots, but they were susceptible when stem-inoculated with race 1 of the pathogen. Severity of root decay was isolate dependent.

Additional keywords: flue-cured tobacco, Nicotiana tabacum

Phytophthora parasitica Dast. var. nicotianae (Breda de Haan) Tucker causes a serious root and stem disease of tobacco (Nicotiana tabacum L.) called black shank and has been distributed throughout the United States and in many tobacco-growing regions of the world $(6,9,11,15,16)$. Although management programs utilizing cultural practices, resistance, and chemical treatments exist (12), losses in some years can be severe. Both race 0 and race 1 of the pathogen are present in the tobacco-growing areas of the United States, and the pathogen recently has been reported in Georgia (6). Commercial cultivars typically have resistance derived from Florida 301 , which is complexly inherited (2$4,10)$. This resistance is inherited quantitatively for race 0 and 1 but may not be useful to growers in Georgia and Florida, depending on disease pressure or level of resistance conferred to the cultivar $(1,2,6)$. Coker 371-Gold, a commercial cultivar, has high resistance to race 0 but low resistance to race 1 . NC 71 and NC 72, two new cultivars recently developed, show similar resistance traits. The breeding line 1071, which has resistance from Nicotiana plumbaginifolia, has near immunity to race 0 but is susceptible to race 1 , and has been used as an indicator plant to detect race 1 $(6,10)$.

\section{Corresponding author: A. S. Csinos \\ E-mail: csinos@tifton.cpes.peachnet.edu}

Accepted for publication 22 May 1999.

Publication no. D-1999-0618-01R

(C) 1999 The American Phytopathological Society
Carlson et al. (3), using double haploid lines derived from Coker 371-Gold, determined that Coker 371-Gold possesses a single, dominant gene that confers complete resistance to race 0 , but not to race 1 , of $P$. parasitica var. nicotianae North Carolina isolates. Studies have documented the fact that tobacco stems and leaves are very susceptible to invasion by $P$. parasitica var. nicotianae $(10,18,19)$. However, researchers have not been able to correlate resistance of aboveground tissue sufficiently to relate it to cultivar resistance. Atypical symptoms of black shank, consisting of aboveground collapse of stem tissue and typical black necrotic stem lesions in the absence of root necrosis, have been reported by researchers across the U.S. tobacco-growing area $(8,11,16,19)$. However, most of the emphasis was placed on recognition and proper diagnosis of black shank, and little attention has been placed on atypical symptoms and their relationship to epidemiology of the disease.

This study investigates atypical black shank symptoms and their relationship to the epidemiology of the disease and the relative levels of susceptibility of tobacco stem and root tissues to infection by $P$. parasitica var. nicotianae.

\section{MATERIALS AND METHODS}

Field evaluations. In 1993, tobacco plants were collected from several tobacco fields in the Coastal Plain of Georgia. Samples were collected from Tift, Atkinson, Pierce, Coffee, and Irwin counties representing cultivars K326, Speight G-70, and McNair 944. Twenty-five plants, just as they started to show wilt symptoms, were selected from each of the 15 P. para- sitica var. nicotianae-infested fields. Plants were carefully uprooted, trimmed above any existing lesions, and transported to the laboratory in coolers. At the laboratory, plants were washed and split longitudinally, and the internal lesion was measured in both directions from the soil line. Lesion ratios were calculated, with the numerator being lesion length above the soil line and the denominator the lesion length below the soil line for each plant. The percentage of the 25-plant sample with ratios greater than one and the percentage with ratios less than one were calculated.

Greenhouse. $P$. parasitica var. nicotianae race 0 and race 1 used in this study were isolated from tobacco fields in Georgia. Isolate 305 was isolated from Speight G-70 in Jeff Davis County, isolates 364, 421, and 432 from K326 in Tift County, and isolates 424 from 1071 and 435 from Coker 371-Gold in Tift County. Inocula were prepared by sterilizing and infesting toothpicks with the test organism (6). Toothpicks were autoclaved in V8 juice for $15 \mathrm{~min}$ at $121^{\circ} \mathrm{C}$, allowed to cool, placed on potato dextrose agar-filled petri plates, and inoculated with a 5-mm plug from actively growing cultures of $P$. parasitica var. nicotianae. Plates were incubated at $27^{\circ} \mathrm{C}$ in the dark for 10 to 14 days, allowing the fungus to grow across the plates and into the media-impregnated toothpicks. Plants were inoculated by aseptically pushing the infested toothpicks into stems 2 to $3 \mathrm{~cm}$ above the soil line or into root systems near the base of the plant. Uninfested toothpicks acted as controls. Tobacco cultivars Hicks, NC2326, McNair 944, K326, NC79, Speight G-108, Speight G-28, K394, Speight G-70, K346, Coker 371-Gold, and NC71, and the breeding line 1071 , listed generally in order of increasing resistance (race 0), were started from seed and grown 6 to 8 weeks to seedling size in float tray systems managed as recommended by the Georgia Cooperative Extension Service (12). Test plants were 15 to $20 \mathrm{~cm}$ tall, with a stem diameter of 5 $\mathrm{mm}$, and were transferred to separate trays just prior to inoculation. Greenhouse temperature was managed with heaters and fan-assisted cooling pads, which resulted in temperatures ranging from 15 to $25^{\circ} \mathrm{C}$ during the tests. Each treatment had 5 to 36 plants, depending on the test. The cultivar inoculation combinations were kept in separate trays and placed in separate float baths to prevent cross contamination during the test period. 
Development of stem lesions was evaluated using a linear scale of 1 to 10 , where 1 was no disease and 10 was a dead plant. Ratings were taken on stems 3 to 16 days postinoculation. Roots were evaluated by washing them and then rating them on a scale of 0 to $100 \%$ of the root system necrotic. Stem disease progress was evaluated in all tests; root necrosis was evaluated only in root inoculation tests.

Data were analyzed by ANOVA or GLM procedures of SAS. Significant difference among means was determined by Duncan's multiple range test at $P=0.05(13,17)$.

\section{RESULTS}

Field evaluations. Many plants with aboveground lesions, but without obvious root deterioration, were found in all but one field location (Table 1). Often, decay was focused around a leaf scar, suggesting that as the point of infection. The percentage of plants with lesions larger above than below the soil line varied from 0 to $84 \%$ in

Table 1. Observations of Phytophthora parasitica var. nicotianae-infected plants collected from Georgia tobacco fields

\begin{tabular}{lcccc}
\hline Sample location & County & $\begin{array}{c}\text { \% above } \\
\text { soil line }^{\mathbf{z}}\end{array}$ & $\begin{array}{c}\text { \% below } \\
\text { soil line }\end{array}$ & Cultivar \\
\hline Black shank nursery 1993 & Tift & 24 & 76 & K326 \\
Black shank farm 1993 & Tift & 28 & 72 & K326 \\
Jimmy McCray farm 1993 & Atkinson & 16 & 84 & K326 \\
Jimmy Grantham farm 1993 & Atkinson & 84 & 16 & K326 \\
Van Steedley farm 1993 & Pierce & 56 & 44 & Speight G-70 \\
R. E. Bennett farm 1993 & Pierce & 60 & 40 & K326 \\
Curtis Hunter farm 1993 & Irwin & 60 & 40 & K326 \\
Gene Daniels farm 1993 & Irwin & 12 & 88 & K326 \\
Smith-Quin farm 1994 & Coffee & 33 & 67 & Speight G-70 \\
Smith-Walker farm 1994 & Coffee & 0 & 100 & K326 \\
Arrington farm 1994 & Tift & 5 & 95 & K326 \\
Black shank farm 1994 & Tift & 30 & 70 & K326 \\
Trowell farm 1994 & Tift & 47 & 53 & K326 \\
Pridgen farm 1994 & Coffee & 82 & 18 & McNair 944 \\
Burdette farm 1994 & Tift & 11 & 89 & K326 \\
\hline
\end{tabular}

${ }^{\mathrm{z}}$ Lesions were measured from soil line up and from soil line down. Stem lesion length was numerator; below soil line lesion length was denominator. If number was $\geq 1$, plant was scored in percent above soil line; if number was $<1$, plant was scored in percent below soil line.

Table 2. Effect of inoculation point and tobacco cultivar on disease stem rating and root rot rating for Phytophthora parasitica var. nicotianae race 0

\begin{tabular}{|c|c|c|c|}
\hline Cultivar & Inoculation point $^{v}$ & Stem lesions ${ }^{w}$ & Root infection $^{x}(\%)$ \\
\hline \multicolumn{4}{|l|}{ Trial 1} \\
\hline K326 & Root & $1.0 \mathrm{~b}^{\mathrm{y}}$ & $30 \mathrm{~b}$ \\
\hline \multirow[t]{2}{*}{ (susceptible) } & Soil line & $4.4 \mathrm{~b}$ & $43 \mathrm{ab}$ \\
\hline & Stem & $8.8 \mathrm{a}$ & $84 \mathrm{a}$ \\
\hline Speight G-70 & Root & $1.0 \mathrm{c}$ & $29 \mathrm{~b}$ \\
\hline \multirow[t]{2}{*}{ (moderate resistance) } & Soil line & $5.2 \mathrm{~b}$ & $45 \mathrm{ab}$ \\
\hline & Stem & $8.0 \mathrm{a}$ & $83 \mathrm{a}$ \\
\hline & Root & $1.0 \mathrm{a}$ & $26 \mathrm{a}$ \\
\hline \multirow{2}{*}{ (resistant) } & Soil line & $3.2 \mathrm{a}$ & $6 \mathrm{~b}$ \\
\hline & Stem & $2.8 \mathrm{a}$ & $13 \mathrm{~b}$ \\
\hline \multirow[t]{3}{*}{$1071^{z}$} & Root & $1.8 \mathrm{a}$ & $17 \mathrm{a}$ \\
\hline & Soil line & $1.0 \mathrm{~b}$ & $5 \mathrm{~b}$ \\
\hline & Stem & $1.0 \mathrm{~b}$ & $3 \mathrm{~b}$ \\
\hline \multicolumn{4}{|l|}{ Trial 2} \\
\hline K326 & Root & $3.6 \mathrm{a}$ & $90 \mathrm{a}$ \\
\hline \multirow{2}{*}{ (susceptible) } & Soil line & $8.4 \mathrm{~b}$ & $100 \mathrm{a}$ \\
\hline & Stem & $10.0 \mathrm{c}$ & $100 \mathrm{a}$ \\
\hline \multirow{3}{*}{$\begin{array}{l}\text { Coker 371-Gold } \\
\text { (resistant) }\end{array}$} & Root & $1.0 \mathrm{a}$ & $5 \mathrm{~b}$ \\
\hline & Soil line & $3.6 \mathrm{~b}$ & $8 \mathrm{a}$ \\
\hline & Stem & $3.6 \mathrm{~b}$ & $6 a b$ \\
\hline \multirow{3}{*}{1071} & Root & $1.0 \mathrm{a}$ & $5 \mathrm{a}$ \\
\hline & Soil line & $2.4 \mathrm{a}$ & $9 \mathrm{a}$ \\
\hline & Stem & $2.4 \mathrm{a}$ & $4 \mathrm{a}$ \\
\hline
\end{tabular}

${ }^{\mathrm{v}}$ In root balls, at soil line, and in stems $2.5 \mathrm{~cm}$ above soil line with race 0 of $P$. parasitica var. nicotianae.

${ }^{\text {w }}$ Disease stem rating based on a scale of 1 to 10 , where $1=$ healthy plant and $10=$ dead plant. Stems were rated 1 week after inoculation. Each site-cultivar combination consisted of five plants.

${ }^{x}$ Root infection was based on percent roots necrotic. Data were taken 4 weeks after inoculation. Each site-cultivar combination consisted of five plants.

${ }^{y}$ Means arranged vertically within cultivars followed by the same letter are not significantly different according to Duncan's multiple range test $(P=0.05)$.

${ }^{\mathrm{z}}$ Tobacco breeding line with near immunity to race 0 but susceptibility to race 1 .

the fields surveyed. Five of the 15 fields surveyed had a higher percentage of plants with aboveground lesions longer than belowground lesions. All locations except one had some atypical black shank symptoms, with large stem lesions and minor or no root infection.

Greenhouse. Inoculations of the stem caused a rapid collapse of the tissue. A delay in disease development was observed when the inoculation point was at the soil line or in the root (Table 2). The rate of disease progress was slower in trial one than in trial two. Root necrosis severity was greater for both K326 and Speight G70 on stem-inoculated plants than on rootinoculated plants, and those inoculated at the soil line were intermediate in root necrosis. In resistant cultivars such as Coker 371-Gold and breeding line 1071, severity of disease was much reduced for both stem disease severity and root necrosis.

Fourteen to 16 days were required for disease to progress from the root system into the stem and kill the susceptible cultivar Hicks (Table 3). In contrast, stem-inoculated plants were killed in 3 days. All cultivars showed a delayed disease response when root inoculated compared with stem inoculation. Very little disease occurred on the cultivar Coker 371-Gold and the breeding line 1071 when stem inoculated, and no disease was detected on stems when plants were root inoculated.

In another similar trial, all cultivars except Hicks developed very little stem disease when plant roots were inoculated (Table 4). Root disease was low to moderate for all cultivars except Hicks, which had high root necrosis. All cultivars except Coker 371-Gold, NC71, and 1071 showed severe disease within 3 days of inoculation into the stems, and within 10 days those cultivars were dead. All cultivars displayed severe stem disease when inoculated with race 1 of $P$. parasitica var. nicotianae (isolates 424 and 435) (Table 5). However, cultivars Coker 371-Gold and 1071 showed no disease reaction in the stems when inoculated with race 0 (isolates 421 and 432). Cultivar NC79 had less stem disease than other cultivars when inoculated with isolate 435 but was susceptible to all other isolates.

Root infections were low in Coker 371Gold and 1071 when they were inoculated with race 0 . However, a great deal of variability in root infection occurred when roots were inoculated with race 1 (Table 5). Isolate 435 (race 1) caused a 100\% decay of 1071 roots, while isolate 424 (race 1) caused only 3\% decay in 1071, similar to that experienced with the two isolates of race 0 .

\section{DISCUSSION}

Atypical symptoms of black shank, also known as stem black shank, have been observed in the tobacco-growing areas of the United States for decades $(8,11,16,19)$. 
The survey of field samples examined in this study suggests that atypical symptom development may be more common now on our current cultivars than was described by previous workers. Five of the 15 fields evaluated in 1993 and 1994 had greater lesion development above the root-stem interface than below. In many cases, infection was negligible below the soil line. Stem lesions longer than lesions below the soil line could represent either an initial infection above the soil line or more rapid growth through susceptible stem tissue or both.

Researchers have suggested that resistance to $P$. parasitica var. nicotianae is typically manifested in the root systems where soilborne pathogens reside $(4,5,10,14)$. These data support the conclusion that roots are more resistant than stems. Resistance derived from Fla 301 is limited to root systems and does not provide resistance to aerial plant parts. The cultivar Hicks had low resistance in both the root and the stem. Cultivars such as NC2326, K-326, McNair 944, Speight G-70, and K346 demonstrated increasing levels of root resistance but still had low stem resistance. However, breeding line 1071, cultivar Coker 371-Gold, and in one study, NC71 demonstrated high levels of resistance in both the roots and the stems when inoculated with race 0 of $P$. parasitica var. nicotianae.

Carlson et al. (3) demonstrated the presence of the $P h$ gene in Coker 371-Gold and stated that it was complete resistance to race 0 of $P$. parasitica var. nicotianae but conferred no resistance to race 1 . This work supports those findings but suggests that resistance is also conferred to stems of tobacco in addition to root systems. Carlson et al. (3) used a naturally infested black shank disease nursery and greenhouse root inoculations to draw their conclusions, but they never distinguished between root and stem resistance in the array produced in their double haploid lines.

Coker 371-Gold has long been recommended (12) as the cultivar with the high- est level of resistance to tobacco black shank in Georgia. In these studies, Coker 371-Gold demonstrates, not only a high level of resistance in the root, but also a very high level of resistance in stems. In an earlier study (6) and in this study, Coker 371-Gold appeared to be heavily damaged by race 1 of the pathogen but very tolerant to race 0 . Although the cultivar has high resistance, some of its agronomic characteristics, such as lodging and low yield, make it unpopular with growers. Growers often cultivate to build soil around the base of the plant, and that practice may contribute to increased black shank, especially under wet conditions. The cultivar NC71, which demonstrated high resistance to race 0 , was released for commercial use in 1997, so there is limited experience with that cultivar in $P$. parasitica var. nicotianae-infested fields.

There are at least two types of resistance acting against $P$. parasitica var. nicotianae. One appears to be manifested in the root systems and the other in the stems of plants. Most contemporary cultivars have Florida 301 resistance to black shank, which appears to be inherited quantitatively, and resistance is expressed primarily in root systems. The breeding line 1071 has $N$. plumbaginifolia parentage as part of its resistance, while Coker 371-Gold has Florida 105 resistance, recently described as the $P h$ gene (3). These and previous studies suggest they are similar $(3,6)$. The Fla 105 resistant parent of Coker 371-Gold has been lost (7), and thus studies on that donor parent cannot be done. The quantity of resistance donated by Fla 301 to Coker 371-Gold is unknown, and we do not know if the Fla 105 parent conferred only stem resistance or contributed additional root resistance to the cultivar. Several researchers have discussed the inheritance of resistance from Fla 301, Nicotiana longiflora, and $N$. plumbaginifolia into commercial cultivars $(1-4,10)$. As indicated by Carlson et al. (3), the resistance from

Table 4. Effect of stem or root inoculation on stem lesion development and root decay by Phytophthora parasitica var. nicotianae race 0

\begin{tabular}{lccccc}
\hline & \multicolumn{2}{c}{$\begin{array}{c}\text { Stem lesions }^{\mathbf{u}} \\
\text { (root inoculated) }\end{array}$} & \multirow{2}{*}{$\begin{array}{c}\text { Root } \\
\text { infection }(\%)\end{array}$} & \multicolumn{2}{c}{$\begin{array}{c}\text { Stem lesions } \\
\text { (stem inoculated) }\end{array}$} \\
\cline { 2 - 3 } Cultivar & Day 3 & Day 6 & Day 10 & Day 3 & Day 6 \\
\hline Hicks & $1.2 \mathrm{a}^{\mathrm{y}}$ & $6.7 \mathrm{a}$ & $47.0 \mathrm{a}$ & $8.4 \mathrm{a}$ & $10.0 \mathrm{a}$ \\
NC2326 & $1.1 \mathrm{ab}$ & $1.5 \mathrm{bc}$ & $19.0 \mathrm{~b}$ & $7.8 \mathrm{~b}$ & $10.0 \mathrm{a}$ \\
K326 & $1.1 \mathrm{ab}$ & $1.2 \mathrm{c}$ & $13.0 \mathrm{bcd}$ & $7.6 \mathrm{~b}$ & $10.0 \mathrm{a}$ \\
McNair 944 & $1.1 \mathrm{ab}$ & $1.3 \mathrm{bc}$ & $15.0 \mathrm{bcd}$ & $7.8 \mathrm{~b}$ & $10.0 \mathrm{a}$ \\
Speight G-70 & $1.0 \mathrm{~b}$ & $1.4 \mathrm{bc}$ & $18.0 \mathrm{bc}$ & $7.6 \mathrm{~b}$ & $10.0 \mathrm{a}$ \\
K346 & $1.1 \mathrm{ab}$ & $1.9 \mathrm{~b}$ & $18.0 \mathrm{bc}$ & $7.7 \mathrm{~b}$ & $10.0 \mathrm{a}$ \\
Coker 371-Gold & $1.0 \mathrm{~b}$ & $1.1 \mathrm{c}$ & $8.0 \mathrm{~d}$ & $1.2 \mathrm{~d}$ & $1.2 \mathrm{c}$ \\
NC 71 & $1.0 \mathrm{~b}$ & $1.0 \mathrm{c}$ & $9.3 \mathrm{~cd}$ & $1.6 \mathrm{c}$ & $1.6 \mathrm{~b}$ \\
1071 & $1.1 \mathrm{ab}$ & $1.1 \mathrm{c}$ & $9.0 \mathrm{~d}$ & $1.7 \mathrm{c}$ & $1.7 \mathrm{~b}$ \\
\hline
\end{tabular}

u Disease rating based on a scale of 1 to 10 , where $1=$ no disease reaction and $10=$ plant dead. Each cultivar had 36 individual plants for each of the two inoculation sites.

${ }^{v}$ Plants inoculated by plunging a $P$. parasitica var. nicotianae (race 0 ) infested toothpick into seedling rootball.

${ }^{\text {w}}$ Stems inoculated by inserting a $P$. parasitica var. nicotianae-infested toothpick into seedling stems $2.5 \mathrm{~cm}$ above soil line.

${ }^{\mathrm{x}}$ Days postinoculation.

${ }^{y}$ Means in the same column followed by the same letter are not significantly different according to Duncan's multiple range test $(P=0.05)$.

${ }^{z}$ Tobacco breeding line with near immunity to race 0 but susceptibility to race 1 .

Table 3. Effect of stem or root inoculation on stem lesion development by Phytophthora parasitica var. nicotianae race 0

\begin{tabular}{|c|c|c|c|c|c|c|c|c|c|}
\hline \multirow[b]{3}{*}{ Cultivar } & \multicolumn{9}{|c|}{ Stem lesions ${ }^{\mathbf{u}}$} \\
\hline & \multicolumn{6}{|c|}{ Root inoculated $^{v}$} & \multicolumn{3}{|c|}{ Stem inoculated $^{\mathrm{w}}$} \\
\hline & Day $3^{x}$ & Day 7 & Day 9 & Day 11 & Day 14 & Day 16 & Day 3 & Day 7 & Day 9 \\
\hline Hicks & $1.8 \mathrm{a}^{\mathrm{y}}$ & $7.2 \mathrm{a}$ & $8.5 \mathrm{a}$ & $8.6 \mathrm{a}$ & $9.1 \mathrm{a}$ & $9.1 \mathrm{a}$ & $9.7 \mathrm{a}$ & $9.7 \mathrm{a}$ & $9.7 \mathrm{a}$ \\
\hline NC2326 & $1.3 \mathrm{~b}$ & $3.3 \mathrm{~b}$ & $3.9 \mathrm{~b}$ & $4.5 \mathrm{~b}$ & $4.8 \mathrm{~b}$ & $4.8 \mathrm{~b}$ & $10.0 \mathrm{a}$ & $10.0 \mathrm{a}$ & $10.0 \mathrm{a}$ \\
\hline K326 & $1.2 \mathrm{~b}$ & $1.9 \mathrm{c}$ & $2.4 \mathrm{c}$ & $2.8 \mathrm{c}$ & $2.9 \mathrm{c}$ & $2.9 \mathrm{c}$ & $9.5 \mathrm{ab}$ & $9.7 \mathrm{a}$ & $9.7 \mathrm{a}$ \\
\hline McNair 944 & $1.2 \mathrm{~b}$ & $1.9 \mathrm{c}$ & $2.2 \mathrm{~cd}$ & $2.3 \mathrm{~cd}$ & $2.7 \mathrm{c}$ & $2.8 \mathrm{c}$ & $10.0 \mathrm{a}$ & $10.0 \mathrm{a}$ & $10.0 \mathrm{a}$ \\
\hline Speight G-70 & $1.1 \mathrm{~b}$ & $1.9 \mathrm{c}$ & $2.1 \mathrm{~cd}$ & $2.2 \mathrm{~cd}$ & $2.4 \mathrm{c}$ & $2.4 \mathrm{c}$ & $10.0 \mathrm{a}$ & $10.0 \mathrm{a}$ & $10.0 \mathrm{a}$ \\
\hline K346 & $1.1 \mathrm{~b}$ & $1.3 \mathrm{c}$ & $1.3 \mathrm{~cd}$ & $1.5 \mathrm{~cd}$ & $1.9 \mathrm{~cd}$ & $1.9 \mathrm{~cd}$ & $9.2 \mathrm{~b}$ & $9.9 \mathrm{a}$ & $10.0 \mathrm{a}$ \\
\hline Coker 371-Gold & $1.0 \mathrm{~b}$ & $1.0 \mathrm{c}$ & $1.0 \mathrm{~d}$ & $1.0 \mathrm{~d}$ & $1.0 \mathrm{~d}$ & $1.0 \mathrm{~d}$ & $1.3 \mathrm{c}$ & $1.3 \mathrm{~b}$ & $1.3 \mathrm{~b}$ \\
\hline $1071^{\mathrm{z}}$ & $1.0 \mathrm{~b}$ & $1.0 \mathrm{c}$ & $1.0 \mathrm{~d}$ & $1.0 \mathrm{~d}$ & $1.0 \mathrm{~d}$ & $1.0 \mathrm{~d}$ & $1.6 \mathrm{c}$ & $1.5 \mathrm{~b}$ & $1.5 \mathrm{~b}$ \\
\hline
\end{tabular}

${ }^{\mathrm{u}}$ Disease rating was based on a scale of 1 to 10 , where $1=$ no disease reaction and $10=$ plant dead. Each cultivar had 36 individual plants for each inoculation site.

${ }^{\mathrm{v}}$ Roots inoculated by plunging a $P$. parasitica var. nicotianae (race 0 ) infested toothpick into seedling root ball.

${ }^{\text {w }}$ Stems inoculated by inserting a $P$. parasitica var. nicotianae (race 0 ) infested toothpick into seedling stems $2.5 \mathrm{~cm}$ above soil line.

${ }^{x}$ Days postinoculation.

y Means in same column followed by the same letter are not significantly different according to Duncan's multiple range test $(P=0.05)$.

${ }^{\mathrm{z}}$ Tobacco breeding line with near immunity to race 0 but susceptibility to race 1 . 
Table 5. Effect of stem and root inoculation on tobacco cultivars with race 0 and race 1 of Phytophthora parasitica var. nicotianae

\begin{tabular}{|c|c|c|c|c|c|c|c|c|}
\hline \multirow[b]{2}{*}{ Cultivar } & \multicolumn{2}{|c|}{ Isolate $421^{v}$} & \multicolumn{2}{|c|}{ Isolate 424} & \multicolumn{2}{|c|}{ Isolate 432} & \multicolumn{2}{|c|}{ Isolate 435} \\
\hline & Stem ${ }^{w}$ lesions & $\begin{array}{c}\operatorname{Root}_{(\%)} \\
\end{array}$ & Stem lesions & $\begin{array}{c}\text { Root decay } \\
(\%)\end{array}$ & Stem lesions & $\begin{array}{c}\text { Root decay } \\
(\%)\end{array}$ & Stem lesions & $\begin{array}{c}\text { Root decay } \\
(\%)\end{array}$ \\
\hline $1071^{\mathrm{y}}$ & $1.0 \mathrm{c}^{\mathrm{z}}$ & $6 \mathrm{~cd}$ & $10.0 \mathrm{a}$ & $3 \mathrm{~b}$ & $1.0 \mathrm{~b}$ & $3 a$ & $10.0 \mathrm{a}$ & $100 \mathrm{a}$ \\
\hline K326 & $10.0 \mathrm{a}$ & 28 abcd & $10.0 \mathrm{a}$ & $5 \mathrm{~b}$ & $10.0 \mathrm{a}$ & $22 \mathrm{a}$ & $10.0 \mathrm{a}$ & $41 \mathrm{~b}$ \\
\hline Coker 371-Gold & $1.0 \mathrm{c}$ & $2 \mathrm{~d}$ & $10.0 \mathrm{a}$ & $6 \mathrm{~b}$ & $1.0 \mathrm{~b}$ & $3 a$ & $10.0 \mathrm{a}$ & $9 \mathrm{c}$ \\
\hline NC 79 & $10.0 \mathrm{a}$ & $43 \mathrm{ab}$ & $9.2 \mathrm{a}$ & $11 \mathrm{~b}$ & $10.0 \mathrm{a}$ & $42 \mathrm{a}$ & $4.0 \mathrm{~b}$ & $6 \mathrm{c}$ \\
\hline Speight G-108 & $10.0 \mathrm{a}$ & $43 \mathrm{ab}$ & $10.0 \mathrm{a}$ & $45 \mathrm{a}$ & $10.0 \mathrm{a}$ & $31 \mathrm{a}$ & $10.0 \mathrm{a}$ & $51 \mathrm{~b}$ \\
\hline Speight G-28 & $10.0 \mathrm{a}$ & 10 bcd & $8.5 \mathrm{a}$ & $5 \mathrm{~b}$ & $10.0 \mathrm{a}$ & $26 a$ & $10.0 \mathrm{a}$ & $23 \mathrm{bc}$ \\
\hline Speight G-70 & $10.0 \mathrm{a}$ & $37 \mathrm{abc}$ & $10.0 \mathrm{a}$ & $2 b$ & $10.0 \mathrm{a}$ & $43 \mathrm{a}$ & $10.0 \mathrm{a}$ & $20 \mathrm{bc}$ \\
\hline K394 & $9.5 \mathrm{~b}$ & $47 \mathrm{a}$ & $7.7 \mathrm{a}$ & $4 b$ & $10.0 \mathrm{a}$ & $22 \mathrm{a}$ & $10.0 \mathrm{a}$ & $23 \mathrm{bc}$ \\
\hline K346 & $10.0 \mathrm{a}$ & 23 abcd & $10.0 \mathrm{a}$ & $9 \mathrm{~b}$ & $10.0 \mathrm{a}$ & $25 \mathrm{a}$ & $10.0 \mathrm{a}$ & $25 \mathrm{bc}$ \\
\hline
\end{tabular}

v Isolates 421 and 432 are race 0 and isolates 424 and 435 are race 1.

${ }^{w}$ Stems inoculated by inserting a $P$. parasitica var. nicotianae-infested toothpick into seedling stems $2.5 \mathrm{~cm}$ above soil line. Disease rating based on a scale of 1 to 10 , where $1=$ no disease reaction and $10=$ dead plant. Each cultivar-isolate combination was replicated six times. Data recorded 12 days postinoculation.

x Roots inoculated by pushing a $P$. parasitica var. nicotianae-infested toothpick into root balls. Roots were evaluated 25 days postinoculation on a percent decay basis.

y Tobacco breeding line with near immunity to race 0 but susceptibility to race 1 .

${ }^{z}$ Means in columns with the same letter are not significantly different according to Duncan's multiple range test, $P=0.05$.

Coker 371-Gold is a single dominant gene, which when combined with high Fla 301 resistance should provide superior black shank resistance. Additional work will be required to provide and demonstrate resistance to race 1.

Both Coker 371-Gold and the new cultivar NC71 showed similar reactions to inoculations. Neither cultivar was developed specifically for stem resistance to $P$. parasitica var. nicotianae, but they were selected based on their survivability in field disease nurseries. The author suspects that the high levels of resistance expressed by these cultivars are based not only on their resistance to root invasion but also on their high stem resistance. Variability in virulence occurs within races of $P$. parasitica var. nicotianae (Table 1) $(1,6)$, which makes resistance in tobacco cultivars difficult to assess. Although Coker 371-Gold has been reported to have complete race 0 resistance (3), race 0 isolates have damaged Coker 371-Gold and to a lesser extent the breeding line 1071 (Table 5) (6).

Since stem tissue of some cultivars appears to be more susceptible to fungal infection than roots, high losses to the disease may result under conditions that favor lower stem infections, such as heavy cultivation, stem damage, and violent thunderstorms $(11,16)$. Cultivars with low stem resistance develop black shank faster when infection takes place through the stem than through the root system (Table 2). Development of new cultivars such as NC71 with both root and stem resistance will be useful in management programs for tobacco black shank. The influence of race 1 of $P$. parasitica var. nicotianae on the development of disease on both stem and root in current tobacco cultivars and advanced breeding lines or cultivars under development is being studied.

\section{ACKNOWLEDGMENTS}

I thank Philip Morris Tobacco Company and the Georgia Agricultural Commodity Commission for Tobacco for financial support, Wanda Tillery and Lewis Mullis for technical support, and Darlene Willis for typing the manuscript.

\section{LITERATURE CITED}

1. Apple, J. L. 1957. Pathogenic, cultural, and physiological variation within Phytophthora parasitica var. nicotianae. Phytopathology 47:733-740.

2. Apple, J. L. 1962. Physiological specialization within Phytophthora parasitica var. nicotianae. Phytopathology 52:351-354.

3. Carlson, S. R., Wolff, M. F., Shew, H. D., and Wernsman, E. A. 1997. Inheritance of resistance to race 0 of Phytophthora parasitica var. nicotianae from the flue-cured tobacco cultivar Coker 371-Gold. Plant Dis. 81:12691274.

4. Chaplin, J. F. 1966. Comparison of tobacco black shank resistance from four sources. Tob. Sci. 10:55-58.

5. Csinos, A. S., and Bertrand, P. F. 1994. Distribution of Phytophthora parasitica var. nicotianae races and their sensitivity to metalaxyl in Georgia. Plant Dis. 78:471-474.

6. Csinos, A. S., Fortnum, B. A., Powell, N. T., Reilly, J. J., and Shew, H. D. 1984. Resistance of tobacco cultivars and candidate cultivars to Phytophthora parasitica var. nicotianae. Tob. Sci. 28:153-155.

7. Csinos, A. S., and Whitty, E. B. 1995. Evaluation of Coker 371-Gold parentage for resistance to Phytophthora parasitica var. nicotianae. (Abstr.) Tobacco Workers Conference, Tampa, FL.

8. Dukes, P. D., Jenkins, S. F., Jr., and Thompson, S. S. 1965. Atypical symptoms of black shank on flue-cured tobacco. Tob. Sci. 9:88-90.

9. Gaines, J. G. 1960. History of black shank in Georgia flue-cured tobacco including spread of the disease in 1959. Plant Dis. Rep. 44:155-158.

10. Hendrix, J. W., and Apple, J. L. 1967. Stem resistance to Phytophthora parasitica var. nicotianae in tobacco derived from Nicotiana longiflora and $N$. plumbaginifolia. Tob. Sci. 11:148-150.

11. Lucas, G. B. 1975. Diseases of Tobacco. 3rd ed. Biological Consulting Associates, Raleigh, NC.

12. Moore, J. M., Dangerfield, C. W., Givan, W. D., Sumner, P., Tyson, A. W., Jones, D. and Bertrand, P. 1995. Georgia Tobacco Growers' Guide. Univ. Ga. Coop. Ext. Serv. Coll. Agric. Environ. Sci.

13. Steel, R. G. D., and Torrie, J. H. 1960. Principles and Procedures of Statistics. McGrawHill Book Co., New York.

14. Stokes, G. W., and Litton, C. C. 1966. Source of black shank resistance in tobacco and host reaction to races 0 and 1 of Phytophthora parasitica var. nicotianae. Phytopathology 56:678-680.

15. Thompson, S. S., Dukes, P. H., and Jenkins, S. F., Jr. 1965. Black shank in flue-cured tobacco in Georgia: Its spread and control since 1959. Plant Dis. Rep. 49:215-217.

16. Todd, F. A. 1981. Flue Cured Tobacco-Producing a Healthy Crop. Tobacco Consultants, Wendell, NC.

17. Waller, A. A., and Duncan, D. B. 1969. A Bayes rule for the symmetric multiple comparison problem. J. Am. Stat. Assoc. 64:14841499.

18. Wills, W. H., and Crews, J. W. 1964. Expression of black shank resistance in leaves of flue-cured tobacco. Phytopathology 54:13561358.

19. Wills, W. H., and Moore, L. D. 1971. Response of some cultivars and lines of tobacco to stem inoculation with Phytophthora parasitica var. nicotianae. Tob. Sci. 15:51-53. 